Corresponding Author: Khristian Edi Nugroho

Soebandrija

Knugroho@binus.edu Khristian.Edi.Nugroho@gmail com

Received: 16 February 2020 Accepted: 5 March 2020

Published: 10 March 2020

Publishing services provided by Knowledge E

(c) Gatot Suharjanto and Khristian Edi Nugroho

Soebandrija. This article is distributed under the terms of the Creative Commons

Attribution License, which permits unrestricted use and redistribution provided that the original author and source are credited

Selection and Peer-review unde the responsibility of the ICLBI (2018) Conference Committee.

G OPEN ACCESS

\section{Logistics and Supply Chain Engineering: Perspectives on Paperless System for Highway Automatic Tollgate (HAT) through Industry 4.0. in Indonesia}

\section{Gatot Suharjanto ${ }^{1}$ and Khristian Edi Nugroho Soebandrija ${ }^{2}$}

${ }^{1}$ Architecture Department, Faculty of Engineering, Bina Nusantara University, Jl. K. H. Syahdan No. 9, Kemanggisan, Palmerah Jakarta 11480 Indonesia

${ }^{2}$ Industrial Engineering Department, Faculty of Engineering, Bina Nusantara University, Jl. K. H. Syahdan No. 9, Kemanggisan, Palmerah Jakarta 11480 Indonesia

\section{Abstract}

This paper elaborates discourse on Highway Automatic Tollgate (HAT) within logistics and supply chain engineering perspectives. The aforementioned HAT and its implementation are complying with the Product Design Engineering's perspectives within theoretical and industrial implementation through Industry 4.0 in Indonesia. The objective of this paper is to intertwine the theoretical perspectives with industrial implementation. The industrial implementation constitutes the effort to implement paperless system for HAT in order to reduce wasted papers that are necessarily needed by user of this HAT, as transaction proof. The result and discussion of this paper comprise several discussions to be considered. To begin with, the result of this paperless system helps the cleaning service officers to reduce their cleaning duty. Furthermore, the result of this paperless system integrates the concept of industry 4.0 within scope of internet of things (IoT) and internet of everything (IoE). Subsequently, the discussion on this paper refers to the discourse on logistics and supply chain engineering perspectives, to ease the transaction proof involving big data. As a result, it reduces significantly the vehicle traffic and time needed to proceed to transaction in the aforementioned HAT. This paper refers to the research methodology within quantitative approach. As future research, it is indispensable to intertwine both aforementioned theoretical and industrial implementation. Both implementation, as future research, need to be integrated within the Asia Region.

Keywords: Big data analytics; internet of things; making Indonesia 4.0; paperless mechanism; product design engineering

\section{Introduction}

Paperless system in Highway Automatic Tollgate (HAT) is expected to integrate the concept of industry 4.0 within scope of internet of things (IOT) and internet of everything (IoE). The mentioned Highway Automatic Tollgate is interchangeably referring to Gardu 
Tol Otomatis (GTO); and known as Highway Automatic Gate. The integration of the aforementioned concept is in the full swing, including the implementation of Industry 4.0 in Indonesia. The connected devices within IoT and IoE are integrated among each other, allowing the smooth operational efficiency [1]. The efficiency result has trigger further industrial implementation in Indonesia, not only within global Industry 4.0, but also within Making Indonesia (MI) as Indonesia's Local Wisdom and Settings. Automotive industry is one of prioritized industries to be implemented within the context of $\mathrm{Ml} 4.0$ in Indonesia perspective. Its exponential growth within automotive industry has simultaneously triggered significant infrastructure development, including highway construction all across Indonesia. The aforementioned highway is categorized as either a paid highway or an unpaid highway. The unpaid highway is intended for general purpose for vehicle public facility, and the paid highway is intended for fast tract vehicles that required specific highway specifications. The latter paid highway refers to the Highway Automatic Tollgate (HAT).

RFID (Radio Frequency Identification) technology and the payment mechanism through social messenger are escalating in its demand within the highway automatic tollgate [4], including the industrial implementation of GSM technology [5--7]. In addition to the GSM technology, there are escalating demands for technology that is linked directly to the driver database which provides the information of the membership and amount of money [8]. For that phenomenon, the driver requires some forms of payment receipt. Paper as payment receipt is still deemed as very popular in many payment transactions including in the HAT. Similarly, this paper payment receipt is considered popular in Indonesia and is still in high demand within payment transactions [9]. Although the era of e-money has been applied across Indonesia, on the other hand, the transaction proof process still remains a paper structure.

This paper proposes, in its result and discussion, the paperless system of the payment receipt. The paperless system integrates the highway automatic tollgate (HAT) with the mechanism of email or Short Message Services (SMS) of the driver through the Internet [10--12]. Once the driver does the transaction before entering the paid highway, the system will identify the data registered the driver data by the system. The system is then will send the receipt of the transaction to the email or the SMS of the driver through the Internet within Big Data Analytics. 


\section{Problem Statement}

The problem statement of this paper indicates the challenge toward the implementation of the payment receipt. The physical evidence of the payment receipt in HAT is still ubiquitous in almost tollgate across Indonesia. To some extent, the drives do not need the payment receipt in terms of physical evidence.

As a consequence, there are significant wasted papers that are printed for payment receipt; and to be scattered at anytime and anywhere near the highway automatic tollgate. Figure 1 and Figure 2 depict the condition in which the unused received etoll payment scattered all over the toll gate. Subsequently, the unused received e-toll payment on the autonomous machine is still piling up and attached in a long printed paper on the aforementioned machine of highway automatic tollgate.

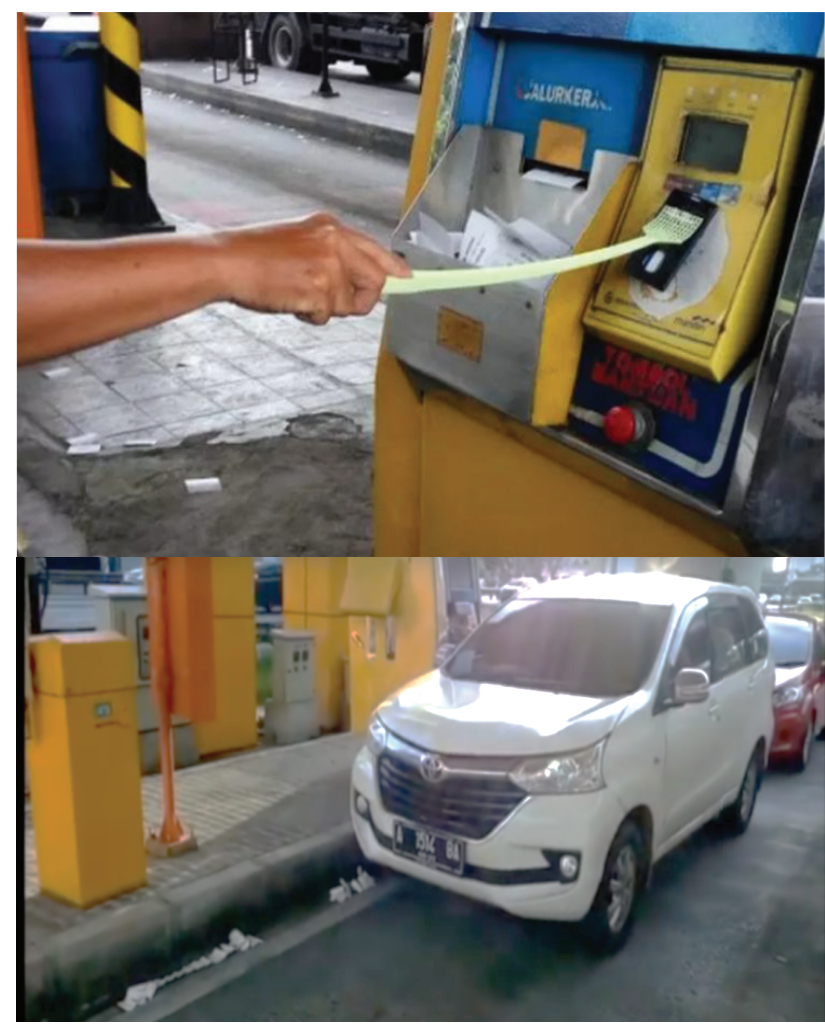

Figure 1: The unused received e-toll payment scattered all over the toll gate

\section{Research questions}

Two significant research questions have been considered in order to enhance the thorough research of this paper. The first research question refers to the question of how to deal with the payment receipt at the highway automatic tollgate (HAT) in 


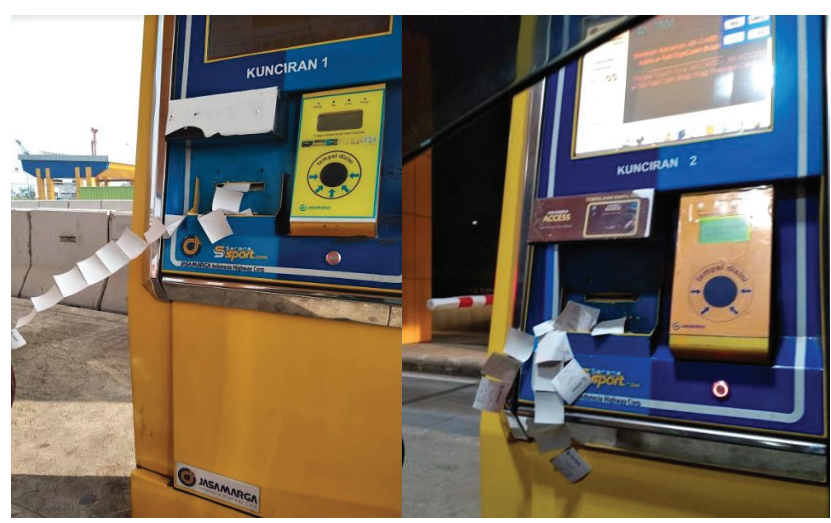

Figure 2: The unused received e-toll payment on the autonomous machine

terms of physical payment receipt. Subsequently, the second research question refers to the question on what are the alternatives as proposed method to reduce the unused physical payment receipt.

\section{Purpose of the study}

The objective of paper is to intertwine the theoretical perspectives with industrial implementation. The theoretical perspectives refer to the related theory within logistics and supply chain engineering. The industrial implementation constitutes the effort to implement paperless system for HAT in order to reduce wasted papers that are necessarily needed by user of this HAT, as transaction proof.

\section{Conceptual models}

The conceptual models in this paper refer to the implementation of paperless system for highway automatic tollgate (HAT). Thus, these models are trying to reduce paper waste from the mechanical system within machine in HAT. The mentioned highway automatic tollgate is interchangeably referring to Gardu Tol Otomatis (GTO) and known as Highway Automatic Gate. The integration of the aforementioned concept is in the full swing, including the implementation of Industry 4.0 in Indonesia.

Paperless system in highway automatic tollgate (HAT) is expected to integrate the concept of industry 4.0 within scope of internet of things (IOT) and the internet of everything (IOE). Both IoT and IoE involve hardware and software integration. In prior to HAT mechanism, drivers are required to tap the e-money card, and by doing so, the system identifies the drivers' data, which are his/her name, phone number. Those data are connected through system and drivers' email as described in Figure 3. 

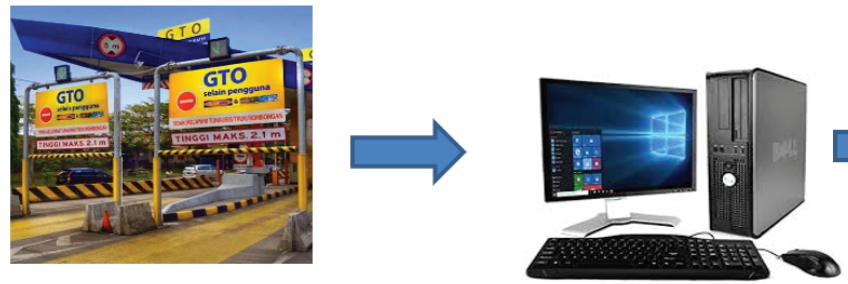

Gerbang Tol Otomatis (GTO) Highway Automatic Gate

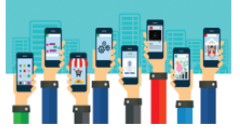

SMS through Customer Handphones
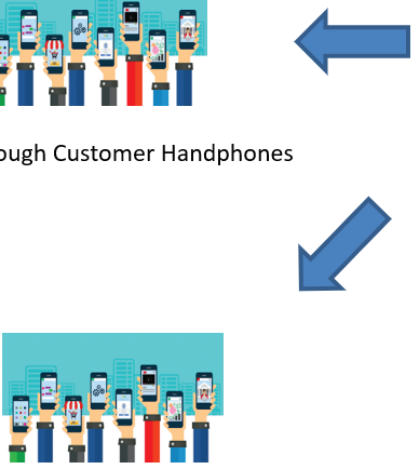

SMS through Customer Handphones

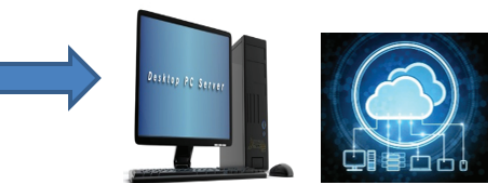

PC Server or Cloud Server

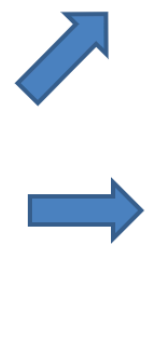

Email through Customer Email

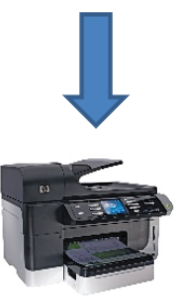

Printed document

Figure 3: Overall the proposed paperless system for Highway Automatic Toolgate (HAT) payment mechanism.

\section{Conclusion}

This paper elaborates discourse on highway automatic tollgate (HAT) within logistics and supply chain engineering perspectives. The aforementioned HAT and its implementation are complying with the product design engineering's perspectives within theoretical and industrial implementation through Industry 4.0 in Indonesia. The objective of this paper is to intertwine the theoretical perspectives with industrial implementation. The industrial implementation constitutes the effort to implement paperless system for HAT in order to reduce wasted papers that are necessarily needed by user of this HAT, as transaction proof.

This paper elaborates the unison of results and discussion in terms of paperless systems. This paperless system is enabling cleaning service officers to reduce their cleaning duty. Subsequently, this paperless system integrates the concept of industry 4.0 within scope of internet of things (IOT) and internet of everything (IoE). The result of this paper is enhanced by discussion on this paper. The aforementioned discussion 
refers to the discourse on logistics and supply chain engineering perspectives, to ease the transaction proof involving big data.

Indonesia is known as a country with challenging traffic conditions. In addition to that, automotive industry is one of prioritized industries to be implemented within the context of Ml 4.0 in Indonesia's perspective. Its exponential growth within automotive industry has simultaneously triggered significant infrastructure development, including highway construction all across Indonesia. The aforementioned highway is categorized as either a paid highway or an unpaid highway. The unpaid highway is intended for general purpose for vehicle public facility, and the paid highway is intended for fast tract vehicles that required specific highway specifications. The latter paid highway refers to the highway automatic tollgate (HAT).

As a result, it reduces significantly the vehicle traffic and time needed to proceed to transaction in the aforementioned HAT. This paper refers to the research methodology within quantitative approach. As future research, it is indispensable to intertwine both aforementioned theoretical and industrial implementation. Both implementation, as future research, need to be integrated within the Asia Region.

\section{References}

[1] Husein AH. Internet of things (IOT): Research challenges and future applications. International Journal of Advanced Computer Science and Applications 2019; 10(6):77--82. http://thesai.org/Downloads/Volume10No6/Paper_11Internet_of_Things_IOT_Research_Challenges.pdf

[2] Hartarto A. Making Indonesia 4.0 [Online] from http://www.kemenperin.go.id/ download/18384 (2016). [Accessed on 6 February 2018]. [in Bahasa Indonesia].

[3] Thamrin H, Kadarudin. Indonesia in the industrial revolution era 4.0: Challenges or threats?. International Journal of Management 2019; January--June:46-57 http://www.ic.rmutk.ac.th/wp-content/uploads/2019/06/International-ManagementJournal-jan-jun.2019.pdf

[4] Fatkhurrahman MA, Syafei WA, Drajat. Perancangan prototipe sistem gerbang tol cerdas berbasis RFID dan notifikasi pembayaran via social messenger [Designing prototypes of RFID-based smart toll gate systems and notification of payments via social messenger]. Transient 2017; 7(4):690--697. [in Bahasa Indonesia]. https: //ejournal3.undip.ac.id/index.php/transient/article/view/18887/0

[5] Vinitha V, Velantina V. Advanced automatic toll collection and vehicle detection system using internet of things. SSRG International Journal of Electrical and 
Electronics Engineering 2019; 6(8):5--10. http://www.internationaljournalssrg.org/ IJEEE/2019/Volume6-Issue8/IJEEE-V6I8P102.pdf

[6] Matta P, Pant B. Internet of things: Genesis, challenges and applications. Journal of Engineering Science and Technology 2019; 14(3):1717--1750. http://jestec.taylors. edu.my/Vol\{\%\}2014\{\%\}20issue\{\%\}203\{\%\}20June\{\%\}202019/14_3_42.pdf

[7] Korade SA, Kotak V, Durafe A. A review paper on internet of things (IoT) and its applications. International Research Journal of Engineering and Technology 2019; 6(6):1623--1630. https://www.irjet.net/archives/V6/i6/IRJET-V6I6376.pdf

[8] Nandhini S, Premkumar P. Automatic toll gate system using advanced RFID and GSM technology. International Journal of Advanced Research in Electrical, Electronics and Instrumentation Engineering 2014, 3(5):13002--13007. https://www.ijareeie.com/ upload/2014/november/26H_Automatic.pdf

[9] Yuliastuti D. (2017). 3 era perkembangan digital payment di Indonesia [3 era of digital development payment in Indonesia]. Digination.id [Online] from https://www. digination.id/read/01513/3-era-perkembangan-digital-payment-di-indonesia (2017). [Accessed on 27 July 2018].

[10] Mithya V, Dharani KV, Nivetha A, Praveen RG, Roshel IM. Smart highway toll collection system. International Journal of Innovative Technology and Exploring Engineering 2019; 8(5):418--421. https://webcache.googleusercontent.com/search?q= cache:nVBRec9c8pgJ:https://www.ijitee.org/wp-content/uploads/papers/v8i5s/ ES3456018319.pdf + cd $=1 \& h l=e n \& c t=c l n k \& g l=i d$

[11] Gade D. ICT based smart traffic management system "iSMART" for smart cities. International Journal of Recent Technology and Engineering 2019; 8(3):1000-1006 https://www.semanticscholar.org/paper/ICT-Enabled-Smart-Parking-System\{\%\}3A-Smartpark-for-Gade/013d0e2b59e799fe1779256790b1916549f45040

[12] Haveli S, Ingle V, Parge P, Bhujbal N, Meher NS. Toll collection system. International Journal of Advanced Research in Computer and Communication Engineering 2019; 8(1):28--30. https://ijarcce.com/wp-content/uploads/2019/02/IJARCCE.2019. 8106.pdf 